\title{
Biliary excretion of antibiotics in man
}

\author{
G. ACOCElla, R. MAtTiUssi, F. B. Nicolis, R. PAllanza, \\ AND L. T. TENCONI
}

From the Department of Clinical Research and Research Laboratories, Lepetit S.p.A., and Ospedale Maggiore, Milano, Italy

The finding that some antibiotics are excreted at levels of therapeutic value in the bile of animals and man is considered a reasonable basis for suggesting their possible usefulness in the treatment of the infections of the biliary tree in man. On this basis the excretion in bile of antibiotics has been a matter of considerable interest in the past twenty years. A review of the more relevant papers producing data obtained in man shows that these studies have been carried out uccording to different experimental procedures, often leading to not comparable or even to conflicting results.

Apart from the differences in dosage, in the time intervals at which the measurements were made, and in the duration of observation, the collection of bile has been usually performed in three different ways, namely, duodenal aspiration, peroperative collection, and biliary drainage.

The duodenal aspiration of bile has been employed for studies on the excretion of penicillin G (Rammelkamp and Helm, 1943), tetracycline (Conti, Cassano, Miano, Mazzeo, and Barletta, 1954), and novobiocin (Conti, Cassano, Barletta, Mazzeo, and Miano, 1957). This procedure can cause irregular results due to dilution of bile by duodenal juice and to periodic emission of concentrated bile from the gall bladder. With some penicillins, furthermore, the antibiotic can be inactivated by the passage of gastric juice at low $p \mathrm{H}$ into the duodenum (Rammelkamp and Helm, 1943).

The peroperative collection of the bile contained in the gall bladder has been employed for studies on penicillin and streptomycin (Zaslow, Counseller, and Heilman, 1947a; Pulaski and Fusillo, 1955; Zoboli, 1955), tetracycline and oxytetracycline (Pulaski and Fusillo, 1955; Zaslow, Cohn, and Ball, 1955; Twiss, Gillette, Berger, Aronson, and Siegel, 1956a; Lambrecht, 1958), tetracycline-l-methylenlisine (Tolio, 1961), and erythromycin (Twiss, Berger, Gillette, Aronson, and Siegel, 1956b). With this mode of collection of bile it is possible to obtain a single measure of the degree of excretion. The results in this condition can be easily biased by the occurrence of total or partial obstruction of the cystic duct, causing difficulty in the penetration of bile, and thus of the antibiotic contained in it, into the gall bladder. Furthermore, even when the cystic duct is patent, the possible presence of stones in the gall bladder lumen can reduce to a considerable extent the space available for bile coming from the liver. It must be remembered that both these conditions are in fact generally present as a cause of the removal of the gall bladder. On the other hand, when the gall bladder is removed in the absence of stones, the influence of water absorption through the gall bladder wall on the concentration of the antibiotic cannot be evaluated.

The biliary drainage by $\mathrm{T}$-tube or biliary fistula has been employed for studies on penicillin and streptomycin (Zaslow, Counseller, and Heilman, 1947b), tetracycline, and oxytetracycline (Herrel, Heilman, and Wellman, 1950; Danopoulos, Angelopoulos, Zioudrou, and Amira, 1954; Maynard, Prigot, and Andriola, 1954-55; Zaslow, Cohn, and Ball, 1954-55a and b; Twiss, Gillette, Berger, Aronson, and Siegel, 1956a; Uberti, 1956), chlortetracycline (Herrell and Heilman, 1949), demethylchlortetracycline (Kunin and Finland, 1959), chloramphenicol (Glazko, Wolf, Dill, and Bratton, 1949), erythromycin (Twiss et al, 1956b; Hammond and Griffith, 1961), rifamycin SV and rifamide (Fürész, Acocella, and Scotti, 1963; Lusena, Acocella, Baroni, and Santilli, 1963; Acocella, Lamarina, Tenconi, and Nicolis, 1966), novobiocin (Martin, Heilman, Nichols, Wellman, and Geraci, 1955), and kanamycin (Preston, Silverman, Henegar, and Neveril, 1959-60). The biliary drainage by T-tube may not allow an accurate quantitative evaluation of the recovery of the antibiotic excreted in bile owing to the incomplete external drainage of bile, although some authors maintain that the drainage of bile through a T-tube in man is virtually complete, provided that the vertical limb of the tube remains unobstructed (Rundle, Cass, Robson, and Middleton, 1955). The loss of antibiotic with the drained bile may also lead to a further underestima- 
tion of the degree of excretion for those antibiotics for which an entero-hepatic circulation can be demonstrated.

However, these two possible sources of error seem to be definitely minor with respect to those affecting the other techniques of bile collection. In particular, neither of them appears to be of any relevance in the estimation of the peak concentration of an antibiotic in the bile.

Concerning the time course of the biliary excretion of antibiotics, a survey of the available data shows that only rarely have the estimations been made at regular time intervals and for more than five hours.

More analytical data on this point are needed, not only for establishing the pattern of the excretion of the different antibiotics in bile, but also for a rational assessment of the dosage schedule. In particular, data obtained during a period of observation, more than five hours are needed after oral administration of antibiotics, as in this case absorption, and biliary excretion in turn, may be delayed.

Further aspects of the biliary excretion of antibiotics, which have not been fully investigated in the past and which appear to deserve further study, include the possible interactions with the excretion of physiological bile components, and the distribution in the human gall bladder wall also in view of their clinical significance.

In an attempt to approach this problem more systematically, a study was undertaken in which the biliary excretion in man of nine antibiotics was evaluated in comparable experimental conditions, employing the biliary drainage by T-tube in patients having undergone surgical operations on the biliary tract. In addition the effect of the treatment on bile volume and on biliary excretion of bilirubin and cholesterol was investigated, and for some antibiotics the concentration in the human gall bladder wall was also estimated.

\section{MATERIAL AND METHODS}

EXCRETION OF ANTIBIOTICS IN BILE AND EFFECT ON SOME BILE VARIABLES Thirty-nine excretion curves were studied in a group of 39 adult female subjects with biliary drainage (T-tube) 7 to 9 days after operation. For each antibiotic, the biliary excretion and the effect on the bile variables were studied for a $12-\mathrm{hr}$ period. The doses of antibiotics chosen for this study were those more commonly used in clinical practice. Each patient received two doses of the compound under study (one dose every six hours), except for penicillin $G$ and the antibiotics administered intravenously which were given in single doses. Bile was collected hourly in tubes protected from light by a wrapping of aluminium foil. The volume of bile was measured and each sample assayed for antibiotic, bilirubin, and cholesterol concentration. Nine experiments were carried out.
Ampicillin ${ }^{1}$ One $250 \mathrm{mg}$ capsule was given every six hours to three subjects (total dose $500 \mathrm{mg}$ ). Two $250 \mathrm{mg}$ capsules were given every six hours to three subjects (total dose $1 \mathrm{~g}$ ).

Cephaloridine $^{2}$ Cephaloridine, $500 \mathrm{mg}$, was given intramuscularly to three subjects every six hours (total dose $1 \mathrm{~g}$ ).

Erythromycin (Lauril sulphate propyonil ester) ${ }^{3}$ One $250 \mathrm{mg}$ capsule was given every six hours to three subjects (total dose $500 \mathrm{mg}$ ).

Novobiocin ${ }^{4}$ Novobiocin, $250 \mathrm{mg}$, was given intramuscularly every six hours to three subjects (total dose $500 \mathrm{mg}$ ). One $250 \mathrm{mg}$ capsule was given every six hours to three subjects (total dose $500 \mathrm{mg}$ ).

Penicillin $G$ One dose of 1,000,000 units (corresponding to $600 \mathrm{mg}$ ) was given intramuscularly to three subjects.

Rifamide $^{5}$ Rifamide, $150 \mathrm{mg}$, was given intramuscularly to six subjects every six hours (total dose $300 \mathrm{mg}$ ).

Rifamycin $S V^{6}$ A single intravenous injection of 250 mg was given to two subjects.

Rolitetracycline $7 \quad$ (Pyrrolidine - methyl - tetracycline $(P M T C)$. PMTC, $275 \mathrm{mg}$, was given as single intravenous injection to two subjects.

Tetracycline $^{8}$ Tetracycline, $100 \mathrm{mg}$, was given intramuscularly every six hours to four subjects (total dose 200 $\mathrm{mg}$ ). One $250 \mathrm{mg}$ capsule of tetracycline was given every six hours to four subjects (total dose $500 \mathrm{mg}$ ).

CONCENTRATION OF ANTIBIOTICS IN THE GALL BLADDER WALL This study was carried out in a group of 18 patients who underwent cholecystectomy. Of these, six were treated with ampicillin, six with novobiocin and six with oxytetracycline ${ }^{9}$. A similar study had already been carried out with refamide in 16 cases (Acocella, Lamarina, Tenconi, and Nicolis, 1966); the results of that study are also reported here for comparative purposes.

Ampicillin, novobiocin, and oxytetracycline were given orally at total doses of $2-2$ and $1 \mathrm{~g}$, respectively, the last dose being usually given one to four hours before surgery. Rifamide was administered at doses of $150 \mathrm{mg}$ eight hourly intramuscularly during one to eight days before operation. At operation gall bladders were collected and kept in sterile tubes. They were cut, washed with saline, weighed and crushed with quartz grains in a mortar. A homogenate, 1:10 w/v with saline, was prepared and centrifuged. Centrifugation resulted in the separation of the material in two phases, a liquid and a solid one. Microscopical examination of the two phases showed that the liquid one was composed of cellular residues, small fragments of cellular organelles, basophilic granules, some microorganisms in the upper part, and of bigger cellular fragments (cellular membranes) and some fibrous residue in the lower part. The solid phase was composed of some cellular residues and almost entirely of quartz grains of different size. There was strong evidence of almost complete homogenization of the gall bladder wall.

The microbiological assay was carried out on the upper,

${ }^{1}$ Amplital, Farmitalia. 'Ceporin, Glaxo. 'Ilosone, Upjohn. 'Vulcamycin, Lepetit. ${ }^{8}$ Rifocin M, Lepetit. 'Rifocin, Lepetit. ${ }^{7}$ Reverin, Hoechst. 'Ambramycin, Lepetit. 'Terramycin, Lederle. 
liquid phase. A preliminary investigation showed that no microbiological activity was present in the solid phase. The concentration of antibiotic in the gall bladder homogenate was carried out according to the method described for the assay in bile.

\section{METHODS OF ASSAY}

ANTIBIOTICs Unless otherwise stated, the agar plate method according to Grove and Randall (1955) was used for the assay of all the antibiotics. Antibiotic concentrations were expressed in terms of $\mu \mathrm{g} / \mathrm{ml}$ or $\mathrm{U} / \mathrm{ml}$ of bile or $\mu \mathrm{g} / \mathrm{ml}$ of gall bladder homogenate. The test microorganism and the lower limit of sensitivity of the standard curve (LLS) for the different antibiotics were as follows:

Ampicillin Sarcina lutea ATCC 9341, LLS 0.09 $\mu \mathrm{g} / \mathrm{ml}$; cephaloridine B.subtilis ATCC 6633, LLS $3 \mu \mathrm{g} / \mathrm{ml}$; erythromycin Sarcina lutea ATCC 9341, LLS 0.15 $\mu \mathrm{g} / \mathrm{ml}$; novobiocin S.aureus ATCC 6538 on Jonagar medium, LLS $1.5 \mu \mathrm{g} / \mathrm{ml}$; oxytetracycline B.cereus var. mycoides ATCC 9364, LLS $0.60 \mu \mathrm{g} / \mathrm{ml}$; penicillin G S.aureus ATCC 6538 , LLS $0.45 \mathrm{U} / \mathrm{ml}$; rifamide $S$.aureus ATCC 6538 , LLS $0.12 \mu \mathrm{g} / \mathrm{ml}$; rifamycin SV Sarcina lutea ATCC 9341, LLS $0.09 \mu \mathrm{g} / \mathrm{ml}$.

The test microorganisms for rolitetracycline and tetracycline were those used in testing oxytetracycline.

BILIRUBIN Bile samples diluted 1:20 were analysed for bilirubin content by the method of Malloy and Evelyn (1937). The concentration of bilirubin was expressed in terms of $\mathrm{mg} / 100 \mathrm{ml}$.

CHOLESTEROL The assay was carried out by the method of Sperry and Webb after extraction of cholesterol carried out according to the method of Foldes (1943). The concentration of cholesterol was expressed in terms of $\mathrm{mg} / 100 \mathrm{ml}$.

\section{RESULTS}

EXCRETION OF ANTIBIOTICS IN BILE The concentrations of the different antibiotics in the bile collected during each hour for a 12-hr period in each individual subject are reported in Figs. 1 to 3 and 5 to 12; Fig. 4 gives the mean values obtained from six subjects with their standard errors. Only the values higher than the lower limit of sensitivity (LLS) of the method of assay are represented in the figures; absence of values at a specified time interval indicates therefore that the concentrations were lower than the lower limits of sensitivity.

\section{ANTIBIOTICS ADMINISTERED INTRAMUSCULARLY}

Cephaloridine (Fig. 1) In one of three subjects studied, microbiological activity lower than the LLS was found throughout the period of observation. In the other two, peak levels of the order of 6 to 10 $\mu \mathrm{g} / \mathrm{ml}$ were found two to three hours from the first

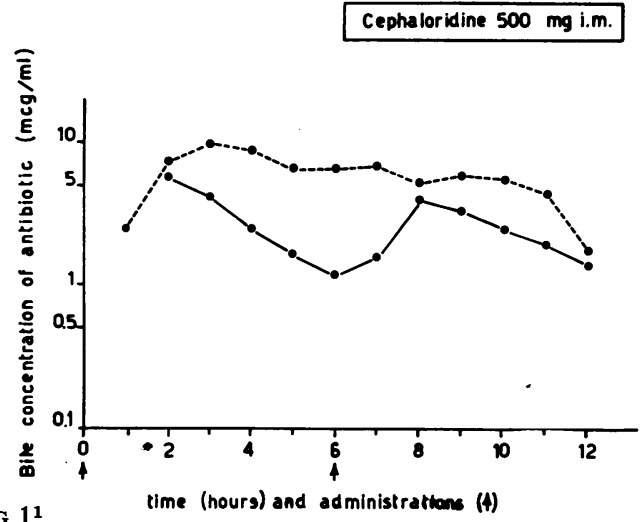

FIG $1^{1}$.

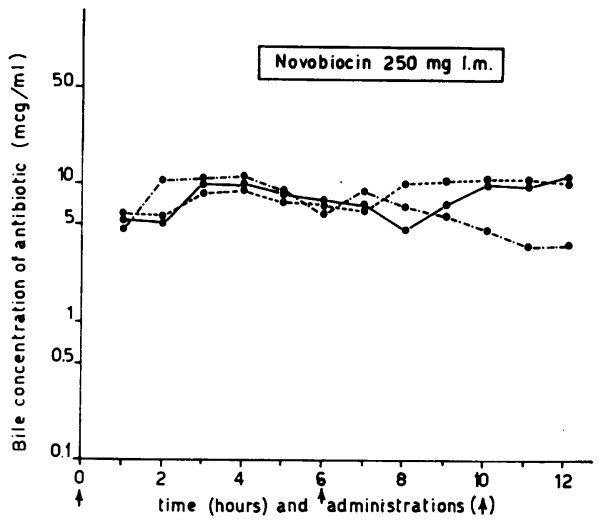

FIG. 2 .

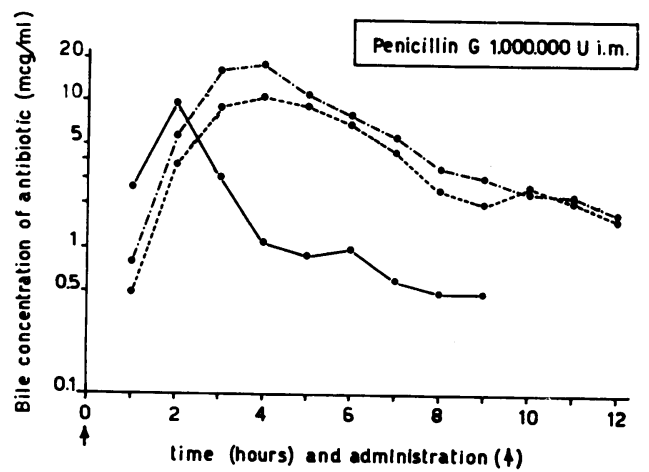

FIG. 3.

${ }^{1}$ In one further subject no measurable antibiotic activity was found. 


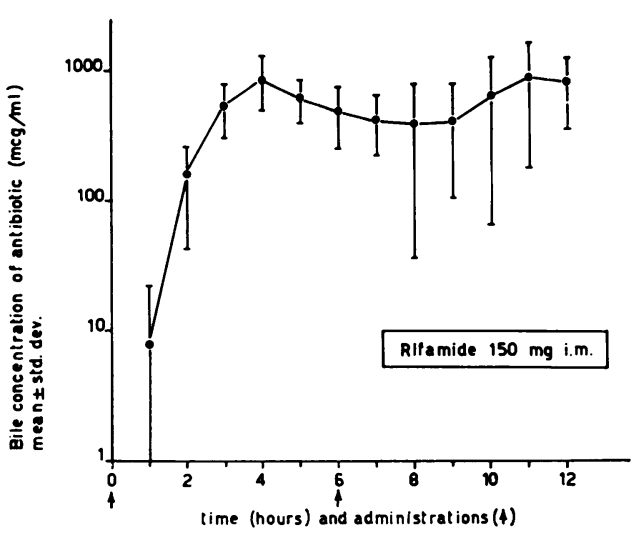

FIG. 4.

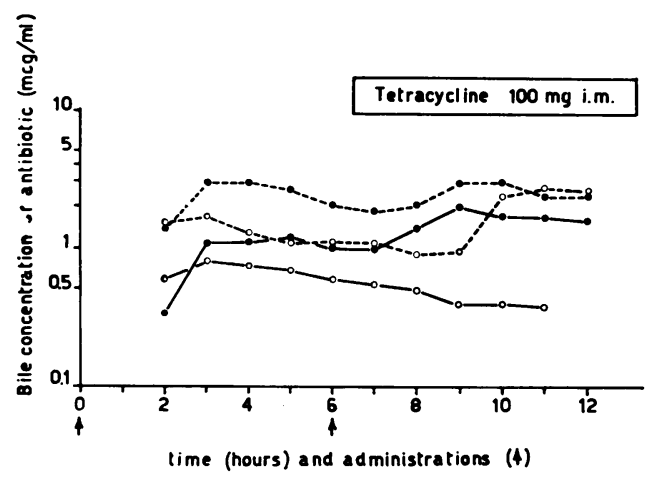

FIG. 5.

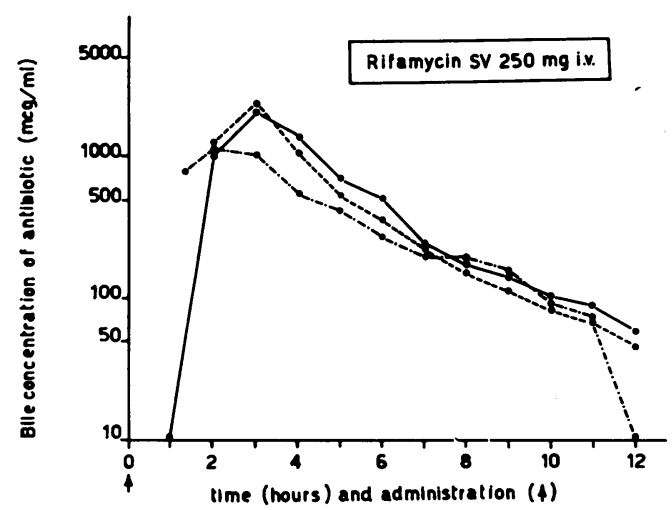

FIG. 6.

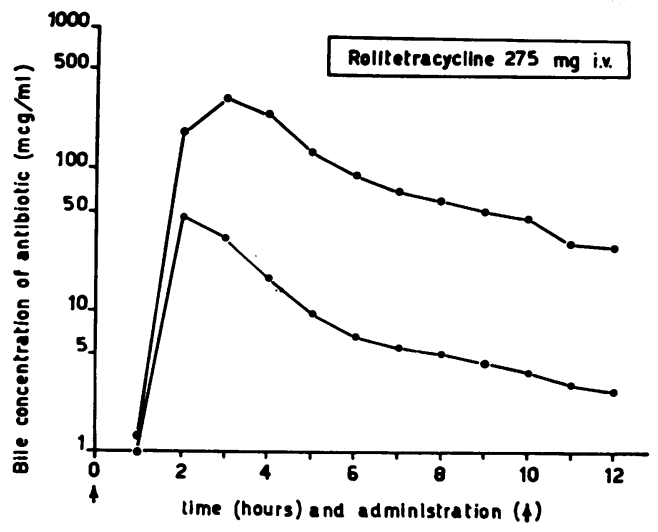

FIG. 7 .

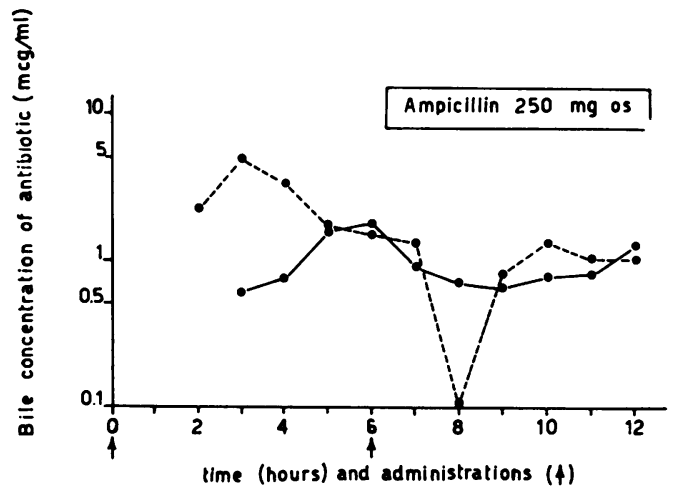

FIG. 81.

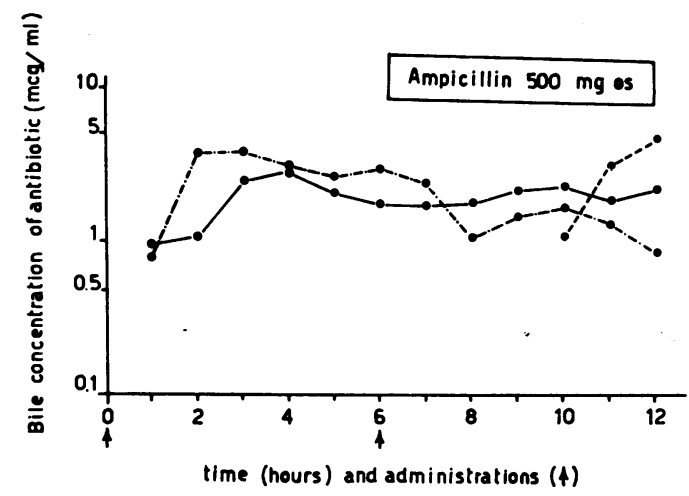

FIG. 9.

${ }^{1}$ In one further subject no measurable antibiotic activity was found. 
administration; the recovery ranged from 0.66 to $1.6 \mathrm{mg}$.

Novobiocin (Fig. 2) The concentration of novobiocin in bile ranged from 5 to $12 \mu \mathrm{g} / \mathrm{ml}$, the recovery from 1.7 to $2.4 \mathrm{mg}$.

Penicillin $G$ (Fig. 3) Peak concentrations of the order of 10 to $20 \mathrm{U} / \mathrm{ml}$ occurred two to four hours after administration. Penicillin was detectable in bile one hour after administration at levels of 0.5 to 2.6 $\mathrm{U} / \mathrm{ml}$. At 12 hours, in two cases, the levels were of the order of 1.6 and $1.8 \mathrm{U} / \mathrm{ml}$, in the third case $0.5 \mathrm{U} / \mathrm{ml}$ was found at nine hours. The recovery ranged from 690 to $900 \mathrm{U}$.

Rifamide (Fig. 4) Peak levels of the order of 900 $\mu \mathrm{g} / \mathrm{ml}$ occurred four to five hours after each injection. The lowest levels found after the second hour (a second administration was carried out six hours after the first) were of the order of $400 \mu \mathrm{g} / \mathrm{ml}$. The recovery ranged from 100 to $200 \mathrm{mg}$.

Tetracycline (Fig. 5) The concentrations ranged from 0.4 to $3 \mu \mathrm{g} / \mathrm{ml}$ from the second hour after administration onwards. The recovery ranged from 71 to $190 \mu \mathrm{g}$.

\section{ANTIBIOTICS ADMINISTERED INTRAVENOUSLY}

Rifamycin SV (Fig. 6) Peak levels occurred at two to three hours with values of the order of 1,200 to $2,400 \mu \mathrm{g} / \mathrm{ml}$. At the following time intervals the concentrations decreased steadily, reaching at 12 hours values of 50 to $60 \mu \mathrm{g} / \mathrm{ml}$ in two subjects and of $10 \mu \mathrm{g} / \mathrm{ml}$ in one subject. The recovery ranged from 53 to $67 \mathrm{mg}$.

Rolitetracycline (Fig. 7) Peak concentrations occurred at two to three hours with values of 45 and $310 \mu \mathrm{g} / \mathrm{ml}$. In the following hours the levels decreased steadily, reaching values at 12 hours of 2.8 and $28 \mu \mathrm{g} / \mathrm{ml}$. The recovery was 1.6 and $12 \mathrm{mg}$.

\section{ANTIBIOTICS ADMINISTERED ORALLY}

Ampicillin When a dose of $250 \mathrm{mg}$ was given (Fig. 8), very irregular levels were observed. Peak concentrations occurred in one case at three hours $(5 \mu \mathrm{g} / \mathrm{ml})$ and in another case at six hours $(1.8$ $\mu \mathrm{g} / \mathrm{ml})$; in one case levels lower than the LLS of the standard curve were observed throughout the period of observation. The recovery was 110 and 220 $\mu \mathrm{g}$. Increasing the dose of ampicillin to $500 \mathrm{mg}$ (Fig. 9) did not result in a corresponding increase in peak concentrations. In two subjects the levels ranged from 1 to $4 \mu \mathrm{g} / \mathrm{ml}$, and in one case the antibiotic was not detectable in bile until the tenth hour. The recovery ranged from 340 to $450 \mu \mathrm{g}$.

Erythromycin (Fig. 10) Peak values were observed at 12 hours with concentrations ranging from $2 \cdot 4$ to $5 \mu \mathrm{g} / \mathrm{ml}$. In two cases erythromycin was detectable in bile during the first hour of observation at levels

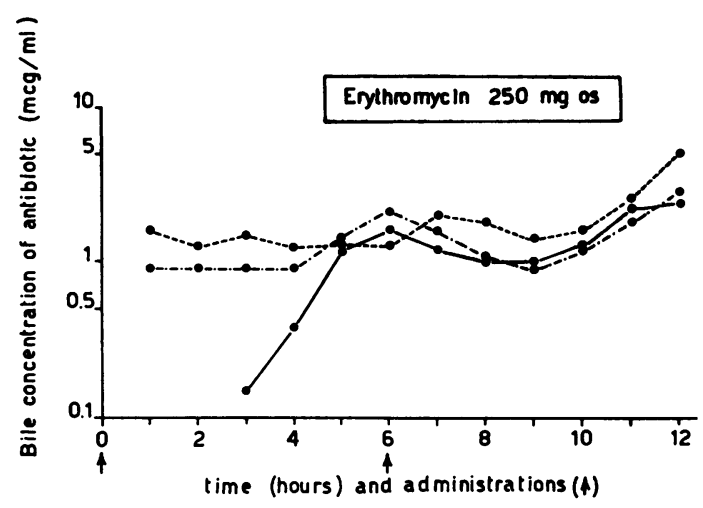

FIG. 10.

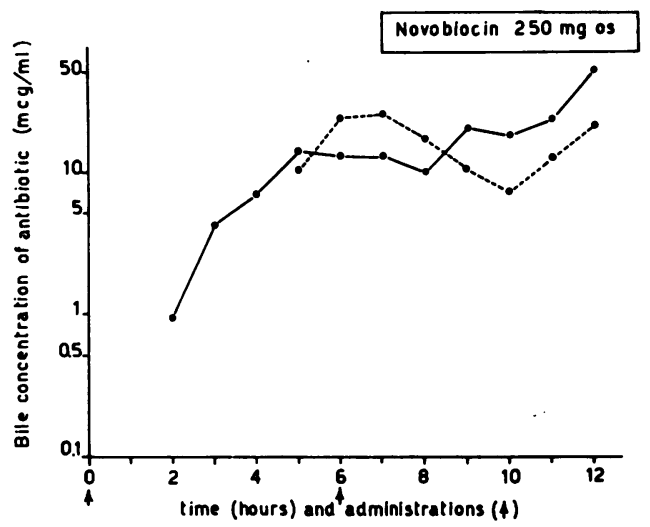

FIG. $11^{1}$.

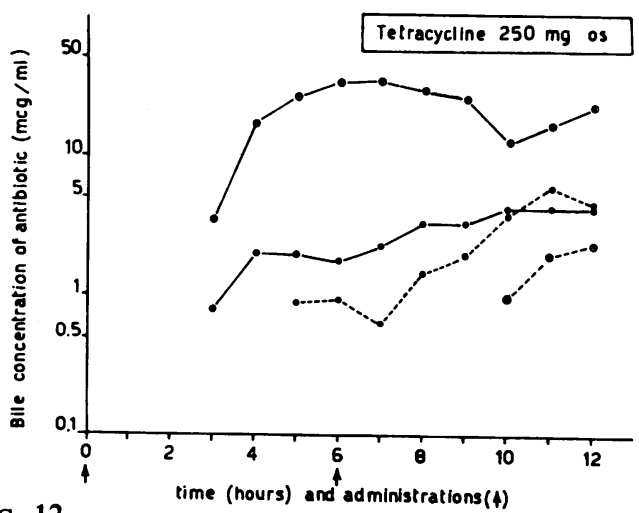

FIG. 12.

${ }^{1}$ In one further subject no measurable antibiotic activity was found. 
TABLE I

BILE VOLUME AND BILIRUBIN AND CHOLESTEROL CONCENTRATIONS IN 32 PATIENTS TREATED WITH DIFFERENT ANTIBIOTICS DURING 12 HOURS AFTER ADMINISTRATION

\begin{tabular}{|c|c|c|c|c|c|c|c|c|c|c|c|c|c|}
\hline \multirow[t]{2}{*}{ Bile Variable } & & \multicolumn{12}{|c|}{ Hours after Administration } \\
\hline & & 1 & 2 & 3 & 4 & 5 & 6 & 7 & 8 & 9 & 10 & 11 & 12 \\
\hline $\begin{array}{l}\text { Volume }(\mathrm{ml}) \\
\text { Bilirubin concentration } \\
(\mathrm{mg} / 100 \mathrm{ml}) \\
\text { Cholesterol concentration } \\
(\mathrm{mg} / 100 \mathrm{ml})\end{array}$ & $\begin{array}{l}\text { Mean } \\
\text { SE } \\
\text { Mean } \\
\text { SE } \\
\text { Mean } \\
\text { SE }\end{array}$ & $\begin{array}{r}14.05 \\
1.00 \\
121 \cdot 87 \\
12 \cdot 81 \\
68.9 \\
8.7\end{array}$ & $\begin{array}{c}13.9 \\
1.03 \\
115.84 \\
11.61 \\
70.5 \\
8.9\end{array}$ & $\begin{array}{c}14 \cdot 2 \\
1.08 \\
119.97 \\
13.08 \\
70.0 \\
8.7\end{array}$ & $\begin{array}{c}14.6 \\
1.06 \\
119.97 \\
13.65 \\
70.4 \\
9.6\end{array}$ & $\begin{array}{c}15 \cdot 0 \\
1.09 \\
119 \cdot 25 \\
13 \cdot 81 \\
69 \cdot 7 \\
9.6\end{array}$ & $\begin{array}{c}15 \cdot 5 \\
1 \cdot 1 \\
119 \cdot 74 \\
14 \cdot 39 \\
66 \cdot 7 \\
8 \cdot 6\end{array}$ & $\begin{array}{c}14 \cdot 4 \\
1.0 \\
120 \cdot 25 \\
13 \cdot 88 \\
65 \cdot 8 \\
9 \cdot 2\end{array}$ & $\begin{array}{c}14.9 \\
1.0 \\
127 \cdot 85 \\
17.97 \\
64.9 \\
8 \cdot 2\end{array}$ & $\begin{array}{c}14 \cdot 7 \\
0.9 \\
122.00 \\
16.85 \\
61.8 \\
8.9\end{array}$ & $\begin{array}{c}14 \cdot 5 \\
1.0 \\
122 \cdot 84 \\
17 \cdot 97 \\
64 \cdot 1 \\
8 \cdot 8\end{array}$ & $\begin{array}{c}15.4 \\
1.1 \\
119.64 \\
16.45 \\
63.9 \\
8.3\end{array}$ & $\begin{array}{c}16.4 \\
1.4 \\
124.83 \\
16.03 \\
67.6 \\
9.4\end{array}$ \\
\hline
\end{tabular}

of 0.9 to $1.6 \mu \mathrm{g} / \mathrm{ml}$; in one case the antibiotic was detectable in the bile at levels higher than the LLS only from the third hour onwards.

Novobiocin (Fig. 11) As compared with the levels observed after intramuscular injection, those seen after oral administration were higher but more irregular and delayed. Peak levels of the order of 24 to $53 \mu \mathrm{g} / \mathrm{ml}$ were observed in two subjects; in one subject levels lower than the LLS of the standard curve were observed throughout the period of observation. The recovery ranged from 2 to $5 \mathrm{mg}$.

Tetracycline (Fig. 12) A great scattering of the concentration values was observed. Peak values occurred in one case at seven hours, in a second case at 12 hours, in the remaining two cases at 11 hours. In two cases microbiological activity higher than the LLS was found from the third hour, in one case from the fifth hour, and in one case from the tenth hour onwards. The recovery ranged from 0.3 to $2 \mathrm{mg}$.

\section{EFFECT OF ANTIBIOTICS ON SOME BILE VARIABLES}

The bile volume and the bilirubin and cholesterol concentrations in the bile showed only minor and irregular variations after the administration of ampicillin, cephaloridine, erythromycin, novobiocin, penicillin $G$, rolitetracycline, and tetracycline, the results obtained have thus been pooled and are summarized in Table I. As can be seen, the hourly flow of bile ranged from $14.0 \pm 1.0 \mathrm{ml}$ to $16.4 \pm 1.4$ $\mathrm{ml}$.

The concentration of bilirubin in bile ranged between $115.8 \pm 11.6$ and $127 \pm 17.9 \mathrm{mg} / 100 \mathrm{ml}$, that of cholesterol between $61.8 \pm 8.9$ and $70.5 \pm$ $8.9 \mathrm{mg} / 100 \mathrm{ml}$.

The only deviations from this general trend were observed in connexion with administration of rifamycin SV and rifamide, when a decrease in both bilirubin and cholesterol concentrations was observed. The data relative to these two compounds, not included in Table $I$, are reported separately in Figures 13 and 14. As can be seen from Fig. 13, after the administration of rifamide the concentration of bilirubin decreased from $110 \mathrm{mg} / 100 \mathrm{ml}$ at one hour to $65 \mathrm{mg} / 100 \mathrm{ml}$ at three hours; then the values remain almost constant until the end of the period of observation. Cholesterol levels decreased steadily from values of $45 \mathrm{mg} / 100 \mathrm{ml}$ at one hour to about $20 \mathrm{mg} / 100 \mathrm{ml}$ at 12 hours. A different trend was observed with rifamycin SV. In fact, with this

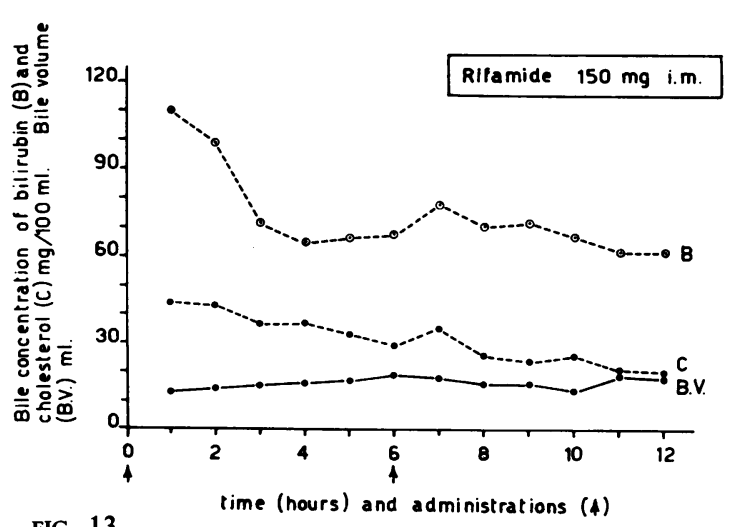

FIG. 13.

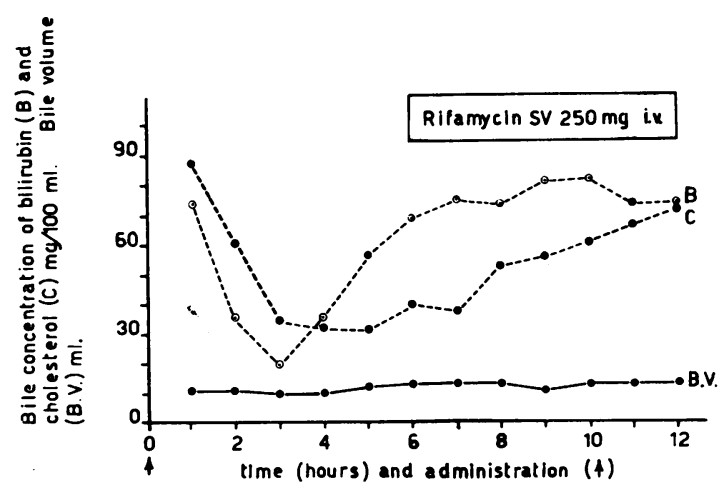

FIG. 14. 
TABLE II

CONCENTRATION OF DIFFERENT ANTIBIOTICS IN THE HUMAN GALL BLADDER WALL AFTER ADMINISTRATION OF THERAPEUTIC: DOSES

\begin{tabular}{|c|c|c|c|c|c|}
\hline Antibiotic & $\begin{array}{l}\text { No. of } \\
\text { Cases }\end{array}$ & $\begin{array}{l}\text { Total Dose } \\
(\mathrm{g})\end{array}$ & Route & $\begin{array}{l}\text { Range of Concentration in the } \\
\text { Homogenate }(\mu g / m l)\end{array}$ & $\begin{array}{l}\text { Estimated Range of Concentration in } \\
\text { the Tissue }(\mu \mathrm{g} / \mathrm{g})\end{array}$ \\
\hline $\begin{array}{l}\text { Ampicillin } \\
\text { Novobiocin } \\
\text { Oxytetracycline } \\
\text { Rifamide }\end{array}$ & $\begin{array}{r}6 \\
6 \\
6 \\
16\end{array}$ & $\begin{array}{l}2 \\
2 \\
1 \\
0.450\end{array}$ & $\begin{array}{l}\text { Oral } \\
\text { Oral } \\
\text { Oral } \\
\text { Intram }\end{array}$ & $\begin{array}{c}<0.20 \\
1.40-3.99 \\
<0.60 \\
1.34-7.85\end{array}$ & $\begin{array}{l}14-40 \\
- \\
14-78\end{array}$ \\
\hline
\end{tabular}

antibiotic, bilirubin and cholesterol levels dropped in a roughly similar way to more than one third of the original value between the first and the third hour, then increased again and reached, at 12 hours, values similar to those seen at the first hour (Fig. 14).

\section{CONCENTRATION OF ANTIBIOTICS IN THE GALL BLADDER WALL}

The data are reported in Table II.

AMPICILLIN In the six patients who had received $2 \mathrm{~g}$ of antibiotic orally the concentration in the gall bladder homogenate was always lower than the LLS of the method used for the determination $(0.20$ $\mu \mathrm{g} / \mathrm{ml})$.

NOvoBIocis In the six patients who had received $2 \mathrm{~g}$ of antibiotic orally, the concentration in the gall bladder homogenate ranged between 1.4 and 4.0 $\mu \mathrm{g} / \mathrm{ml}$, corresponding to a range of 14 to $40 \mu \mathrm{g} / \mathrm{g}$ of tissue.

OXYTETRACYCLINE In the six patients who had received $1 \mathrm{~g}$ of antibiotic orally, the concentration in the gall bladder homogenate was always lower than the LLS of the method used $(0 \cdot 60 \mu \mathrm{g} / \mathrm{ml})$.

RIFAMIDE In 16 patients, the concentration in the gall bladder homogenate ranged between 1.34 and $7.85 \mu \mathrm{g} / \mathrm{ml}$, corresponding to a range of 14 to 78 $\mu \mathrm{g} / \mathrm{g}$ of tissue.

\section{DISCUSSION AND CONCLUSIONS}

When the levels obtained in the bile for the different antibiotics given intramuscularly are compared, it may be seen that, at the peak, the concentrations of rifamide are about 20 times higher than those of novobiocin, 400 times those of tetracycline, and about 100 times those of penicillin $\mathrm{G}$ and cephaloridine.

For the antibiotics administered intravenously, the peak levels of rifamycin SV are about six times as high as those seen in one case with rolitetracycline and 40 times those seen in the second patient treated with this antibiotic.

For the oral route, the administration of novobiocin resulted in antibacterial activity in bile from twice to 10 times higher than that seen with erythromycin derivative, tetracycline, and ampicillin. Doubling the dose of ampicillin did not result in a corresponding increase in biliary excretion. Concerning the excretion of erythromycin, it must be observed that the derivative used by us (propyonil ester) shows a degree of excretion much lower than the parent antibiotic erythromycin (Hammond, 1960). With the oral route, in two sessions no antibiotic activity was detected in bile throughout the period of observation; this was found in one case with novobiocin and in one case with ampicillin. The time of appearance of antibiotic activity in bile was delayed in one case with erythromycin (third hour), novobiocin (fifth hour), tetracycline (tenth hour), and ampicillin (tenth hour), emphasizing the importance of an adequate period of observation in studies carried out with oral antibiotics. In general, after oral administration, very irregular levels were observed as compared to those seen after intramuscular administration, as shown, in particular, by the comparison between the excretion curves observed with the same dose of novobiocin given by oral and by intramuscular routes.

A point deserving discussion concerns the relationship between the amount of antibiotic administered and that recovered in bile. Within each group of antibiotics (in terms of route of administration) a different dosage schedule was used. In the first group (intramuscular route), the range is quite a wide one, including tetracycline which was given at a total dose per experiment of $200 \mathrm{mg}$, and cephaloridine which was given at a dose of $1,000 \mathrm{mg}$. Intermediate doses were those of rifamide $(300 \mathrm{mg})$, novobiocin $(500 \mathrm{mg})$, and penicillin $G(600 \mathrm{mg})$. In the second group (intravenous route), the doses were very similar, being 275 and $250 \mathrm{mg}$ respectively for PMTC and rifamycin SV. In the third group (oral route) the doses were the same for all the antibiotics $(500 \mathrm{mg})$; ampicillin was also given at a double dose $(1,000 \mathrm{mg})$. The estimates of the 12-hr recovery in bile of the different antibiotics calculated on the basis of the 
TABLE III

BILE RECOVERY IN 12 HOURS OF DIFFERENT ANTIBIOTICS AS PERCENTAGES OF ADMINISTERED DOSE

\begin{tabular}{|c|c|c|c|c|}
\hline Antibiotic & Molecular Weight & Route of Administration & Dose (mg) & $\begin{array}{l}\text { Percentage Recovery in Bile } \\
\text { (mean values) }\end{array}$ \\
\hline Ampicillin & $300 \cdot 00$ & Oral & 500 & 0.03 \\
\hline Cephaloridine & 351.41 & Intramuscular & 1000 & 0.06 \\
\hline Penicillin G & $356 \cdot 39$ & Intramuscular & 600 & 0.08 \\
\hline \multirow[t]{2}{*}{ Tetracycline } & 444.43 & Intramuscular & 200 & 0.08 \\
\hline & & Oral & 500 & $0 \cdot 14$ \\
\hline Rolitetracycline & $527 \cdot 56$ & Intravenous & 275 & $0 \cdot 18$ \\
\hline \multirow[t]{2}{*}{ Novobiocin } & 612.65 & Intramuscular & 500 & 0.40 \\
\hline & & Oral & 500 & 0.80 \\
\hline Rifamycin SV & $699 \cdot 77$ & Intravenous & 250 & $25 \cdot 00$ \\
\hline Erythromycin & 733.92 & Oral & 500 & 0.04 \\
\hline Rifamide & $819 \cdot 95$ & Intramuscular & 300 & $34 \cdot 00$ \\
\hline
\end{tabular}

TABLE IV

BILE LEVELS OF DIFFERENT ANTIBIOTICS RELATED TO INHIBITING ACTIVITY ON E.coli PROTEUS, AND Klebsiella-Aerobacter GROUP

\begin{tabular}{|c|c|c|c|c|c|c|c|c|c|c|c|c|c|c|}
\hline \multirow[t]{2}{*}{ Antibiotic } & \multirow{2}{*}{$\begin{array}{l}\text { Route of } \\
\text { Admini- } \\
\text { stration }\end{array}$} & \multirow[t]{2}{*}{$\begin{array}{l}\text { Dose } \\
(m g)\end{array}$} & \multicolumn{3}{|c|}{$\begin{array}{l}\text { MIC }(\mu g / m l) \text { (Majority } \\
\text { or Range) }\end{array}$} & \multicolumn{3}{|c|}{$\begin{array}{l}\text { Peak Levels in Relation to } \\
\text { MIC }\end{array}$} & \multicolumn{3}{|c|}{$\begin{array}{l}\text { Duration of Levels Higher } \\
\text { than MIC }(h r)\end{array}$} & \multicolumn{3}{|c|}{$\begin{array}{l}\text { Time of Appearance of Levels } \\
\text { Higher than MIC }(\mathrm{hr})\end{array}$} \\
\hline & & & E.coli & Proteus & $\begin{array}{l}\text { Klebsiella } \\
\text { Aerobacter }\end{array}$ & E.coli & Proteus & $\begin{array}{l}\text { Klebsiella } \\
\text { Aerobacter }\end{array}$ & E.coli & Proteus & $\begin{array}{c}\text { Klebsiella } \\
\text { Aerobacter }\end{array}$ & E.coli & Proteus & $\begin{array}{l}\text { Klebsiella } \\
\text { Aerobacter }\end{array}$ \\
\hline \multirow[t]{2}{*}{ Ampicillin } & \multirow[t]{2}{*}{ os } & 250 & 8 & $4-R^{1}$ & $16-R^{1}$ & $<$ & $<$ & $<$ & 一 & - & - & - & 一 & - \\
\hline & & 500 & & & & $<$ & $\leqslant$ & $<$ & 一 & 一 & - & 一 & 一 & - \\
\hline Cephaloridine & $\mathrm{im}$ & 500 & $8-R^{1}$ & $8-\mathbf{R}^{1}$ & $8-R^{1}$ & $\leqslant$ & $\leqslant$ & $\leqslant$ & 一 & - & - & - & 一 & - \\
\hline Erythromycin & os & 250 & 100 & $>250$ & $\geqslant 200$ & $<$ & $<$ & $<$ & - & - & - & - & - & - \\
\hline \multirow[t]{2}{*}{ Novobiocin } & os & 250 & 50 & 10 & 10 & $<$ & $\geqslant$ & $\geqslant$ & - & $<1^{2}$ & $<1^{2}$ & - & $<1^{2}$ & $<1^{2}$ \\
\hline & im & 250 & & & & $<$ & $\leqslant$ & $\leqslant$ & - & - & - & - & - & - \\
\hline Penicillin G & $\mathrm{im}$ & 600 & 250 & 250 & 250 & $<$ & $<$ & $<$ & - & - & - & - & - & - \\
\hline Rifamycin SY & iv & 250 & 50 & 50 & 100 & $>$ & $>$ & $>$ & $10-11$ & $10-11$ & $7-8$ & $1-2$ & $1-2$ & $1-2$ \\
\hline Rifamide & $\mathrm{im}$ & 150 & 20 & 20 & 20 & $>$ & $>$ & $>$ & $>10$ & $>10$ & $>10$ & 2 & 2 & 2 \\
\hline \multirow{3}{*}{$\begin{array}{l}\text { Rolitetracycline } \\
\text { Tetracycline }\end{array}$} & iv & 275 & 5 & 125 & 25 & $>$ & $>^{3}$ & $>$ & $5-10$ & $3^{3}$ & $1-10$ & 2 & $2^{8}$ & 2 \\
\hline & os & 250 & 5 & 125 & 25 & $>4$ & $<$ & $<$ & $8^{4}$ & - & - & $4^{4}$ & - & - \\
\hline & im & 100 & & & & $<$ & $<$ & $<$ & - & - & - & - & - & - \\
\hline
\end{tabular}

${ }^{1}$ Resistant ${ }^{2}$ Two out of three cases $\quad{ }^{8}$ One out of two cases $\quad{ }^{4}$ One out of four cases

volumes of the bile drained at hourly intervals and of their antibiotic content may be less accurate than those of the concentrations, owing to the possibility of incomplete drainage of the bile. However, this possible error may be assumed to be randomly distributed and is likely not to be very relevant for the purposes of a rough comparison. This may be carried out on the 12-hour mean percentage recovery figures, reported in Table III.

If all the compounds of each group had the same degree of affinity for the bile, we would expect the dose and recovery in bile to be correlated. The values reported in the table do not provide any evidence suggesting that this correlation takes place. Some correlation seems to exist, on the contrary, between the percentage recoveries and the molecular weights reported in the same table, in agreement with some data of Williams, Smith, and Hillburn (1964) concerning the biliary excretion of large foreign compounds in the rat. The only clear deviation from this hypothesis, given by the erythromycin derivative, might be connected with the modifications purposefully carried out in the molecule of this ester, which lead to a remarkable decrease of biliary excretion as compared to that of the parent compound (Hammond and Griffith, 1960).

A further point which merits discussion concerns the clinical relevance of the concentrations attained by the antibiotics in bile. The inferences which may be drawn from the results of experiments such as the present ones in terms of clinical use of the different antibiotics are clearly only orientative, with the possible exception of a more direct application in those cases in which a postoperative antibiotic 'coverage' is considered necessary. Nevertheless, it appears that some useful information can be obtained by the evaluation of the relationship between concentrations in bile and in vitro activity of the antibiotics against those microorganisms which are more frequently encountered as causative agents of the infections of the biliary tree in man (Fürész, Acocella, and Scotti, 1963).

For the purposes of this study it seemed reasonable to take into consideration, as a term of reference, the 
minimal inhibitory concentrations (MIC) of the antibiotics studied against E.coli, Proteus, and Klebsiella aerobacter, these bacteria being in fact those most frequently found, alone or in association, in the course of infections of the biliary tree. The sensitivity data were those reported for penicillin $G$, erythromycin, novobiocin, and tetracycline by Welch (1959), for ampicillin by Barber and Garrod (1963), for cephaloridine by Murdoch, Speirs, Geddes, and Wallace (1964), for rifamycin SV by Bergamini and Fowst (1965), and for rifamide by Pallanza, Fürész, Timbal, and Carniti (1966). Taking into consideration these data, the results concerning the different antibiotics we studied have been arranged in Table IV according to the following criteria: whether the antibiotics attain in the bile concentrations higher than their MICs against the bacteria selected for the comparison; for how long these levels are maintained; how long it takes from the time of administration for the antibiotics to reach levels fulfilling the above mentioned requirements.

It is evident that only tetracycline, rifamycin SV, and rifamide show levels higher than the MICs for the bacteria; such levels appear within one to four hours after administration and last eight to twelve hours.

Concerning the effects on bile variables, no evidence has been obtained of any effect of the antibiotic treatment on the volume of bile drained. In all experiments, in fact, the volume of bile did not show appreciable variations.

The concentration of bilirubin in bile was of the order of $120 \mathrm{mg} / 100 \mathrm{ml}$, in good agreement with the data obtained by With (1945). In one case values of $20 \mathrm{mg} / 100 \mathrm{ml}$ were observed, while in another levels of 300 to $500 \mathrm{mg} / 100 \mathrm{ml}$ were found, the mean volume of bile being in both these cases $10 \mathrm{ml} / \mathrm{hr}$.

Decrease in bilirubin concentration was observed in connexion with the administration of rifamycin SV and rifamide. For rifamycin SV the hypothesis of a process of competition for excretion between the two substances has been put forward in studies carried out in animals and in man (Acocella and Billing, 1965; Acocella, Nicolis, and Tenconi, 1965). The reduction of bilirubin excretion could therefore be interpreted on the same basis. It seems doubtful whether the observed decrease of bilirubin excretion during rifamide treatment can be interpreted on the same basis or on the basis of spontaneous fluctuations of bilirubin concentrations. Decrease in cholesterol was observed in connexion with treatment with rifamycin SV, ampicillin, and rifamide, the reason for this being, at the moment, obscure.

As far as the concentrations in the gall bladder wall of the four antibiotics tested from this point of view are concerned, ampicillin and oxytetracycline failed to be detected in the gall bladder wall. Rifamide and novobiocin showed, on the contrary, a degree of diffusion similar for the two compounds. The concentrations achieved seem, for both, higher than the MIC against Gram-positive organisms and for rifamide also against the more sensitive strains of Gram-negative bacteria.

In conclusion, the results of this study provide comparable data concerning the biliary excretion of nine antibiotics. They show that intramuscular administration is generally followed by more constant concentrations in bile. Oral administration is likely to produce very irregular levels. With this route, the appearance of antibacterial activity in bile can be delayed and the probability of the antibiotic not being present in bile seems to be higher.

Among the antibiotics studied, the rifamycins are those with the highest degree of affinity for biliary excretion.

We wish to thank Professor B. Austoni for his supervision, Sister Elvira for her collaboration in this investigation and Miss E. Mapelli for her technical assistance.

\section{REFERENCES}

Acocella, G., Nicolis, F. B., and Tenconi, L. T. (1965). The effect of an intravenous infusion of rifamycin SV on the excretion of bilirubin, bromsulphalein, and indocyanine green in man. Gastroenterology, 49, 521-525.

- and Billing, B. H. (1965). The effect of rifamycin SV on bile pigment excretion in rats. Ibid., 49, 526-530.

- Lamarina, A., Tenconi, L. T., and Nicolis, F. B. (1966). Study of the excretion in bile and concentration in the gall bladder wall of rifamide. Gut, 7, 380-386.

Barber, M., and Garrod, L. P. (1963). Antibiotic and Chemotherapy. Livingstone, Edinburgh and London.

Bergamini, N., and Fowst, G. (1965). Rifamycin SV: a review. Arzneimittel-Forsch., 15, 951-1002.

Conti, F., Cassano, A., Miano, G., Mazzeo, M., and Barletta, R. (1954). Un nuovo antibiotico: la tetraciclina. Rif. med., 68, 869-883.

- - - Barletta, R., Mazzeo, M., and Miano, G. (1957). Ricerche sull'assorbimento, diffusione ed eliminazione della novobiocina nell'uomo. Attività in vitro su 50 ceppi di Stafilococco. Min. Med., 48, 245-251.

Danopoulos, E., Angelopoulos, B., Zioudrou, C., and Amira, P. (1954). Experimental study on the absorption of oxytetracycline by the stomach and the small intestine and its excretion in the bile. Antibiot. and Chemother., 4, 451-454.

Foldes, F. F. (1943). The quantitative determination of combined cholesterol in the presence of bile.J. Lab. clin. Med., 28, 18891891.

Fürész, S., Acocella, G., and Scotti, R. (1963). Experimental data for the use of rifamycin SV in biliary tract infections: in vitro activity against various pathogenic bacteria and bile concentrations in man. Chemotherapia, 7, 365-373.

Glazko, A. J., Wolf, L. M., Dill, W. A., and Bratton, A. C., Jr (1949). Biochemical studies on chloramphenicol (chloromycetin). II. Tissue distribution and excretion studies. J. Pharmacol. exp. Ther., 96, 445-459.

Grove, D. C., and Randall, W. A. (1955). Assay Methods of Antibiotics. A Laboratory Manual. (Antibiotics monographs, No. 2). Medical Encyclopedia Inc., New York.

Hammond, J. B., and Griffith, R. S. (1960). Factors affecting the absorption and biliary excretion of erythromycin and two of its derivatives in humans. Clin. Pharmacol. Ther., 3, 308-312.

Herrell, W. E., and Heilman, F. R. (1949). Aureomycin: studies on absorption, diffusion and excretion. Proc. Mayo Clin., 24, 157-166. 
Herrell, W. E., Heilman, F. R., and Wellman, W. E. (1950). Some bacteriologic, pharmacologic and clinical observations on terramycin. Ann. N.Y. Acad. Sci., 53, 448-458.

Kunin, C. M., and Finland, M. (1959). Excretion of demethylchlortetracycline into the bile. New Engl. J. Med., 261, 1069-1071.

Lambrecht, R. (1958). Nachweis von Reverin in der Galle nach parenteraler Anwendung. Klin. Med. (Wien), 53, 1511-1514.

Lusena, M., Acocella, G., Baroni, G. C., and Santilli, E. (1963). Assorbimento ed eliminazione biliare della rifamicina SV nell'uomo. Chemotherapia, 7, 391-400.

Malloy, H. T., and Evelyn, K. A. (1937). The determination of bilirubin with the photoelectric colorimeter. J. biol. Chem., 119, 481-490.

Martin, W. J., Heilman, F. R., Nichols, D. R., Wellman, W. E., and Geraci, J. E. (1955). Streptonivicin (Albamycin): a new antibiotic; preliminary report. Proc. Mayo Clin., 30, 540-551.

Maynard, A. de L., Prigot, A., and Andriola, J. C. (1954-1955). Observations on the absorption, diffusion, and excretion of tetracycline hydrochloride. Antibiot. Ann., 2, 655-658.

Murdoch, J. Mc.C., Speirs, C. F., Geddes, A. M., and Wallace, E. T. (1964). Clinical trial of cephaloridine (Ceporin), a new broadspectrum antibiotic derived from cephalosporin C. Brit. med. $J ., 2,1238-1240$.

Pallanza, R., Fürész, S., Timbal, M. T., and Carniti, G. (1965). In vitro bacteriological studies on rifamycin B diethylamide (rifamide). Arzneimittel.-Forsch., 15, 800-802.

Pulaski, E. J., and Fusillo, M. H. (1955). Gall bladder bile concentrations of the major antibiotics following intravenous administration. Surg. Gynec. Obstet., 100, 571-574.

Preston, F. W., Silverman, M., Henegar, G. C., and Neveril, E. (19591960). The excretion of kanamycin in bile and pancreatic fluid. Antibiot. Ann., 7, 857-861.

Rammelkamp, C. H., and Helm, J. D., Jr (1943). Excretion of penicillin in bile. Proc. Soc. exp. Biol. (N.Y.), 54, 31-34.

Rundle, F. F., Cass, M. H., Robson, B., and Middleton, M. (1955) Bile drainage after choledochostomy in man, with some observations on biliary fistula. Surgery, 37, 903-910.

Sperry, W. M., and Webb, M. (1950). A revision of the SchoenheimerSperry method for cholesterol determination. J. biol. Chem., 187, 97-106.
Tolio, A. (1961). Indagini cliniche sulla eliminazione biliare di una nuova tetraciclina, la tetraciclina-L-metilenlisina, nella occlusione del cistico e del coledoco. Gazz. Sanit., 32, 699-703.

Twiss, J. R., Gillette, L., Berger, W. V., Aronson, A. R., and Siegel, L. (1956a). The role of antibiotics in infections of the biliary tract. Studies in sensitivity and biliary tract excretion. Ann. Surg., 144, 1008-1012.

—, Berger, W. V., Gillette, L., Aronson, A. R., and Siegel, L. (1956b). The biliary excretion of erythromycin (Ilotycin). Surg. Gynec. Obstet., 102, 355-357.

Uberti, E. (1956). Ricerche sull'eliminazione delle tetracicline nelle vie biliari patologiche dell'uomo. Fegato, 2, 169-177.

Welch, H. (1959). A Guide to Antibiotic Therapy. Medical Encyclopedia Inc., New York.

Williams, R. T., Smith, R. L., and Millburn, P. (1964). Conjugation and the biliary secretion of foreign compounds. In Therapeutic Agents and the Liver. Edited by N. McIntyre, and S. Sherlock. p. 37. Blackwell, Oxford.

With, T. K. (1945). Bilirubin and urobilinoid content of human bile. Acta med. scand., 122, 513-528.

Zaslow, J., Counseller, V. S., and Heilman, F. R. (1947a). The excretion and concentration of penicillin and streptomycin in the abnormal human biliary tract. I. Gall bladder. Surg. Gynec. Obstet., 84, 16-20.

,--1 - (1947b). The excretion and concentration of penicillin and streptomycin in the abnormal human biliary tract. II. Hepatic bile. Ibid., 84, 140-152.

—, Cohn, E. M., and Ball, W. (1955). The effect of dehydrocholic acid on the excretion and concentration of oxytetracycline in bile. Antibiot. Med., 1, 151-152.

,$--1-(1954-1955 a)$. The excretion and concentration of tetracycline in the abnormal human biliary tract. Antibiot. Ann., 2, 663-667.

,$--(1954-1955 \mathrm{~b})$. The excretion and concentration of oxytetracycline in bile following intramuscular administration of the drug. Ibid., 964-965.

Zoboli, P. (1955). Concentrazione biliare di alcuni antibiotici in soggetti affetti da colecistopatia. Boll. Soc. Ital. Biol. Sper., 31, 834-835. 